\title{
Geo-tourism Potential of Sand Bars and Oxbow lake at Buluh Cina, Kampar - Riau, Indonesia
}

\author{
Yuniarti Yuskar ${ }^{1}$ * \\ ${ }^{1}$ Geological Engineering, Universitas Islam Riau JI. Kaharuddin Nasution No 113 Pekanbaru, 28284, Indonesia
}

* Corresponding author: yuniarti_yuskar@eng.uir.ac.id

Tel.: +62-82169254941

Received: Oct 1, 2016. Revised : 15 Nov 2016, Accepted: Nov 20, 2016, Published: 1 Dec 2016

DOI : $10.24273 /$ jgeet.2016.11.8

Abstract

Buluh Cina Village is located at Siak Hulu District, Kampar Regency, Riau Province and its about 25 km from Pekanbaru City. This Village is designated as Tourism Village by The Government of Riau Province. This research aims to optimize the potential Geo-tourism by understanding the strengths and weaknesses aspect which is owned by Buluh China Village. So it can increase the number of tourists who visit Buluh Cina Village. The method used is the field survey and literature review . The village is surrounded by a tropical rain forest with an area of over 100 hectares and it divided by the Kampar Kanan River. Fluvial Meandering System of this river form the main channel (river), sandbars, natural levee, floodplain and oxbow lake. Geo-tourism potential that can be developed are sand bars and oxbow lake. Buluh China Village has had a tourist attraction, but there are still some weaknesses, such as floods in the rainy season and some support facilities are not optimal.

Keywords: Geo-Tourism, Sand Bar, Oxbow Lake, Buluh Cina

\section{Introduction}

Buluh Cina Village is plain area with an elevation of $2-6 \mathrm{~m}$ above sea level. The village is divided by the Kampar Kanan which is one of the major river in Riau Province with a length of $413 \mathrm{~km}$. Kampar River on the island of Sumatra in Indonesia originates in the mountainous Bukit Barisan of West Sumatra, and empties into the Malacca Strait on the island's eastern coast. The landscape of research area is characterized mainly by active channels, abandoned channels, natural leeve, back-swamps and floodplain (Yuskar Y and Choanji T., 2016). This makes the village Buluh China as objects Geotourism with sediment Quarter.These instructions are to be followed strictly, and it is strongly advised to use the styles indicated in this document between square brackets. It is strongly advised NOT to use formatting or styles in your paper different from the ones mentioned here.

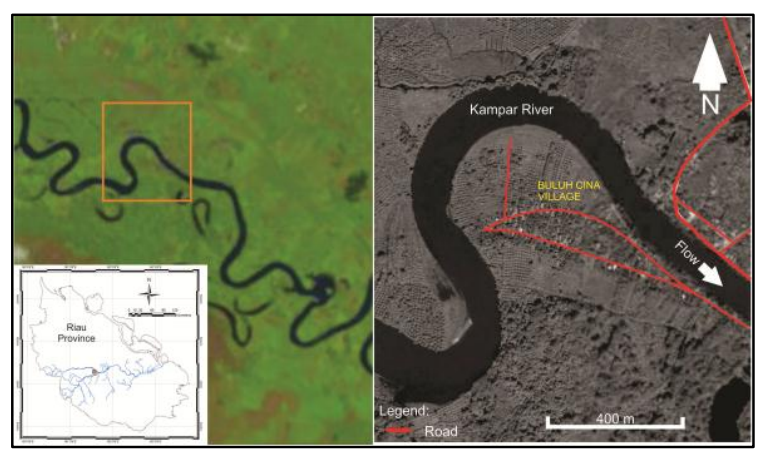

Fig 1. Location of Buluh Cina Village (Yuskar Y and Choanji T., 2016)
Buluh Cina Village designated as Tourism Village by the Government of Riau Province. But seen from the number of tourists who come to the Buluh China village is still few in number. The study aims to optimize the tourism potential, especially Geotourism is owned by the village. Geotourism is tourism activities related to objects and tourist destinations related to geological phenomena (Brahmantyo, 2008).

Buluh Cina Village consists of 4 Hamlet. There are Dusun 1, Dusun 2, Dusun 3 and Dusun 4. Dusun 1 and 2 are located across the Kampar Kanan and to achieve it takes about 5 minutes by boat. In this area there was the tourist sites such as oxbow lakes and sand bar.

\section{Geomorphology and Geological Setting}

Meanders developed by the erosion of bank closest to the thakweg, accompanied by deposition on the opposite side of the channel where flow is sluggish and the bedload can no longer be carried (page 135 Nichols, 2009). Kampar Kanan River is considered as Fluvial Meandering System because there are erosion of the outer bank and deposition of bedload on the inner bank the channel. Sediment deposit on the inner bank is referred to as a point bar. Here distinction between the meandering and river sinuosity

Along The Kampar Kanan River is deposited Young Alluvium (Qh) during Holocene-aged. Young Alluvium (Qh) are consist of gravels, sands and clays. The stratigraphy formation in the Buluh Cina 
Village are Older Alluvium (Qp) aged Pleistocene to Holocene. This sediments are consist of gravels, sands, clays, vegetation rafts and peat swamps (M.C.G. Clarke, W.Kartawa, A.Djunuddin, E. Suganda dan M.Bagdja, 1982).

\section{Methodology}

The methodology used in this research is a field survey and literature review. Field surveys conducted to obtain the location data that can be used as objects of Geo-tourism and pay attention to surrounding circumstances associated with the facilities available to support the Geo-tourism. It also conducted a discussion with local people to obtain daily information society and tourism activities which have been implemented.

\section{Sand Bar Deposit and Oxbow Lake}

\subsection{Sand Bar Deposit}

The basic dynamics of flow around meanders leads to erosion on the outside parts of bends and deposition on the point bars. (Boggs, S.Jr. 2006. p.252). Sediment of point bar deposited medium sand with good sorting and upwards-fining couplets during flood events (Yuniarti and Tiggi, 2016). Point bar located in Kampar Kanan river bends forming a broad sand and beautiful landscape that can be an ideal location as a tourist spot.

Some societies have to capitalize on this location as an interesting tourist attraction to visit but in general, this location still minimal visitors.

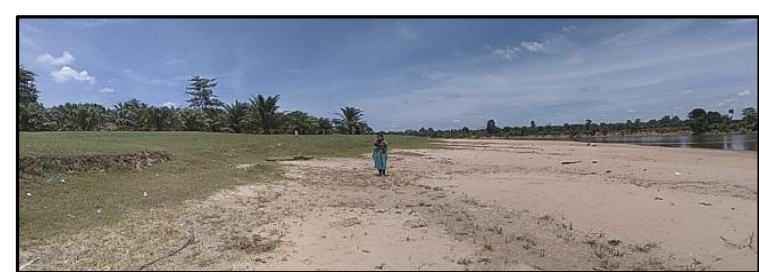

Fig 2. Sand in Kampar Kanan river bends which are sand bars of the fluvial meandering system.

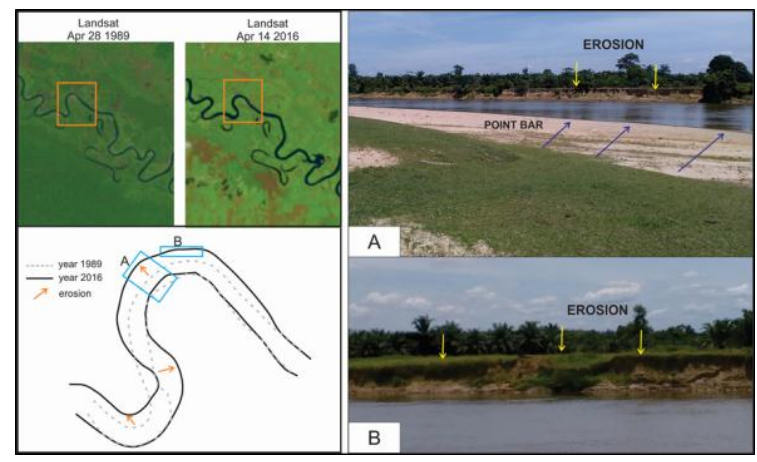

Fig 3. Satellite image that showing geometrical changes the position of the river and image of point bar as result from river migration, and $(B)$. Erosion at the nothern side of the river (Yuskar and Choanji, 2016).

\subsection{Oxbow Lake}

The abandoned meander loop becomes isolated as an oxbow lake and will remain as an area of standing water until it becomes filled up by deposition from floods and or choked by vegetation. The deposits of an oxbow lake may be recognized in ancient fluvial sediments as channel fill made up of fine grained and sometimes carbonaceous (Nichols, 2009).

The formation process of oxbow lake can be an interesting story for tourists. Thus it is necessary given naming to attract tourists. for example calling it "Danau Sungai Purba". Furthermore the local community also have knowledge about unique formation of the lakes in the village.

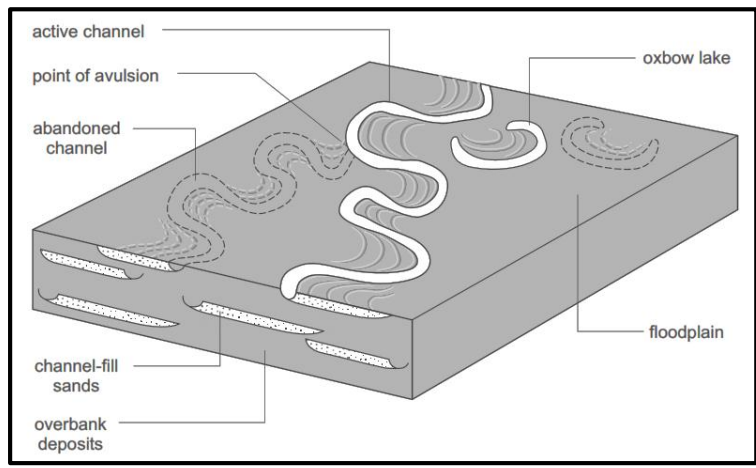

Fig 4. Depositional architecture of a meandering river; sandstone bodies formed by lateral migration of the river channel remain isolated when the channel avulses or is cut-off form an oxbow lake (Nichols, 2009).

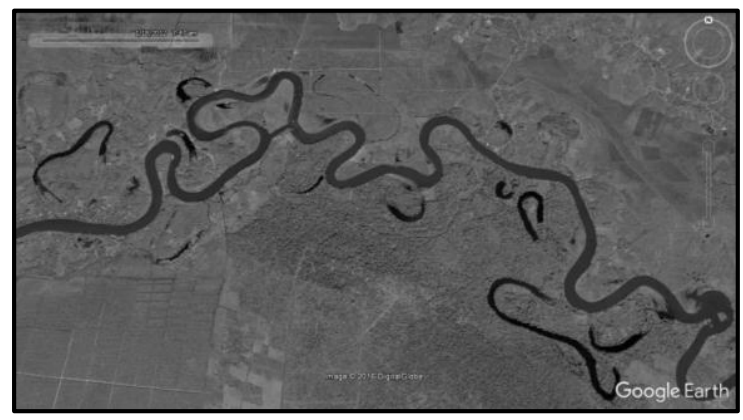

Fig 5. Location of oxbow lakes in the Buluh Cina village (image from Google Earth 2012).

There are 11 oxbow lake in the Buluh Cina village namely Rengas, Rawan, Lagun, Tuok Tonga, New Lake, Tanjung Baling, Pinang Dalam, Pinang Luar, Rayo, Tanjung Baling and Bunte Lake. The lakes is located in the tropical rain forest covers 100 ha. Oxbow lakes have visited both by tourists and researchers in various scientific fields. 


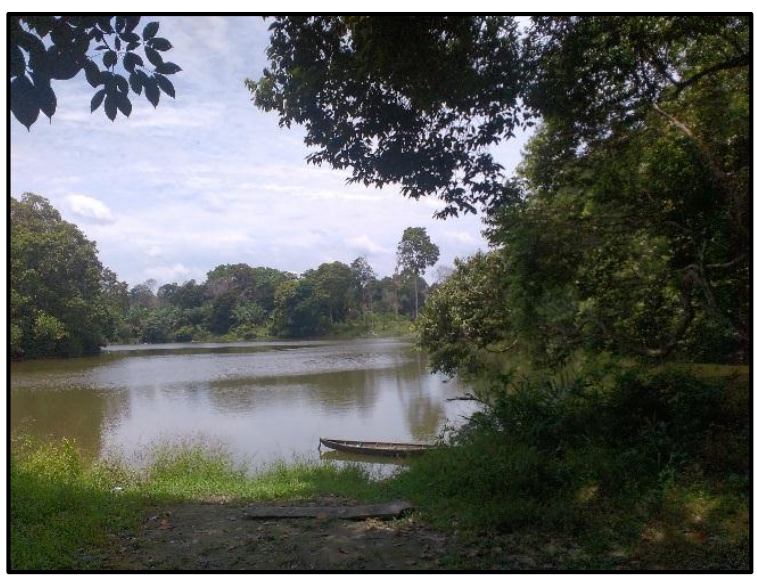

Fig 6. One of the oxbow lakes in Buluh Cina Village

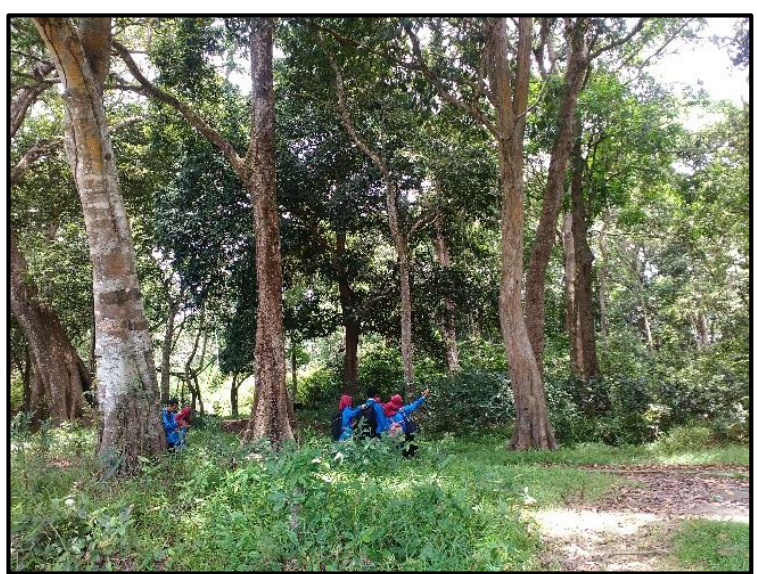

Fig 7. Tropical rain forests around the oxbow lakes

\section{Recommendations Potential Geotourism and Aspects of Disaster in Buluh Cina Village}

Geo-tourism aspects that can be developed in Buluh Cina Village, namely:

a. The presence of the river with the floating ponds and a fish-producing areas with the ecosystem is still maintained. In addition, the river is often used as a location for the people's Party like canoe racing.

b. Sandbars showing a broad of sand and pasture with oil palm trees

c. Oxbow lake with tropical rain forests and lakes into the fishing location for local residents and visitors.

d. Other aspects that can be developed is the cultural aspect. This is indicated by houses on stilts that are home to indigenous Malay population

Besides the potential Geo-tourism is owned by Buluh Cina Village also there is a potential disaster such as flooding and forest fires. Buluh Cina Village is a flood plain. Floodplains are dynamic feature that co-evolve with channel so at present no universal theory is available to predict floodplain width in natural rivers (as a function of drainage area, bankfull discharge, or sediment flux, etc) because floodplain morphology dynamically integrates across these and the other factors, over some unconfined time interval in the environment history of the watershed (Patrick Belmont, 2011).
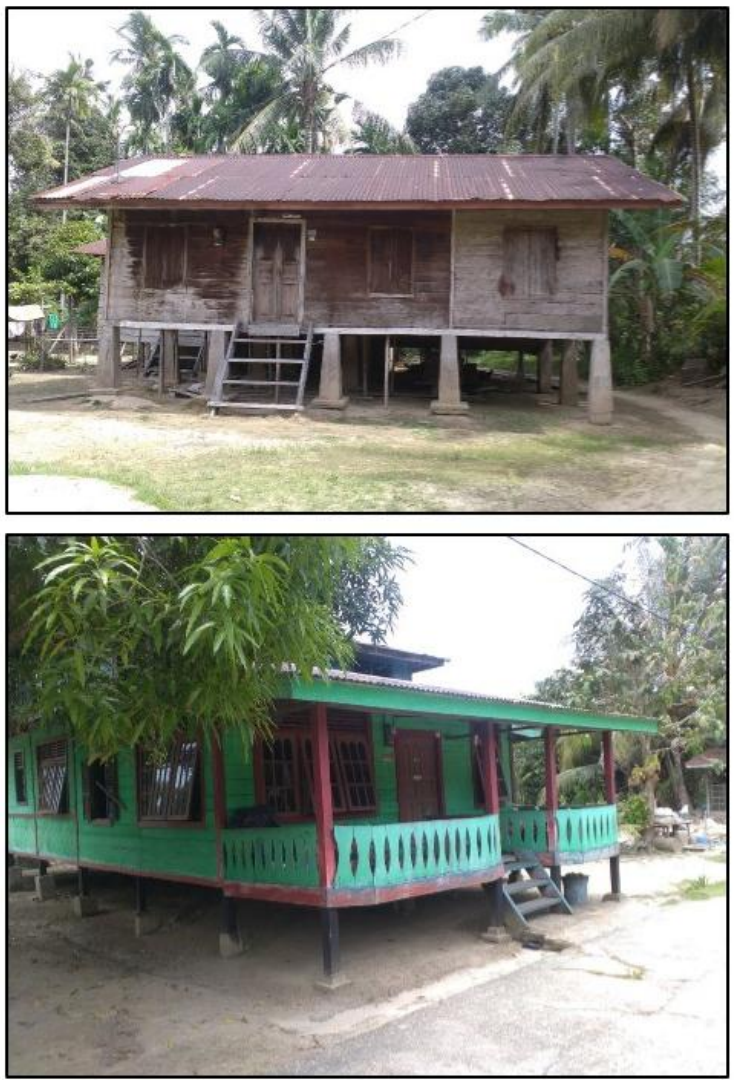

Fig 8. Existing Stilt House at Buluh Cina Village

Floods that happen periodically in this area also bring finer sediment such as silt and mud that characterize overbank deposit but not significant shown in this area. Therefore, in floodplain formation, lateral accretion gives bigger contribution than vertical accretion. Lateral accretion deposit characterize with fine to medium sand while overbank characterize with finer sediment (silt and clay) (Yuskar, 2016).

It should be considered by the community. To overcome the floods that occurred in the rainy season which is by building stilt houses. It is also useful to conserve Malay culture so that it becomes an attraction for tourists.

While in the dry season, forest fires often occur whether caused by natural processes or by human intervention due to land clearing. Then it needs to be increased alertness and severe sanctions to persons who carry out the forest fire.

\section{Optimizing The Utilization of Geo-tourism}

In an effort to utilize optimally Geo-tourism, the local community must be involved and play an active role in managing the Geo-tourism and requiring coordination with government institutions.

Based on the discussions have been done with Buluh Cina Village community, the community have attempted to preserve the nature and the ecosystem in the area. However economic standard is still is low then some people sell the land area and make their land as oil palm plantations. Therefore 
optimization of Geotourism in this area expected to improve the local economies. So that preservation of nature will be maintained.

Several things that should be met, namely establisment and improvement of public facilities. Previously have been built some facilities and signposts by PT. Chevron Pacific Indonesia and named this area as "Desa Eko Wisata Danau Rimbo Tujuh Danau". However, the existing facilities are not well maintained and should be repaired to make it better.

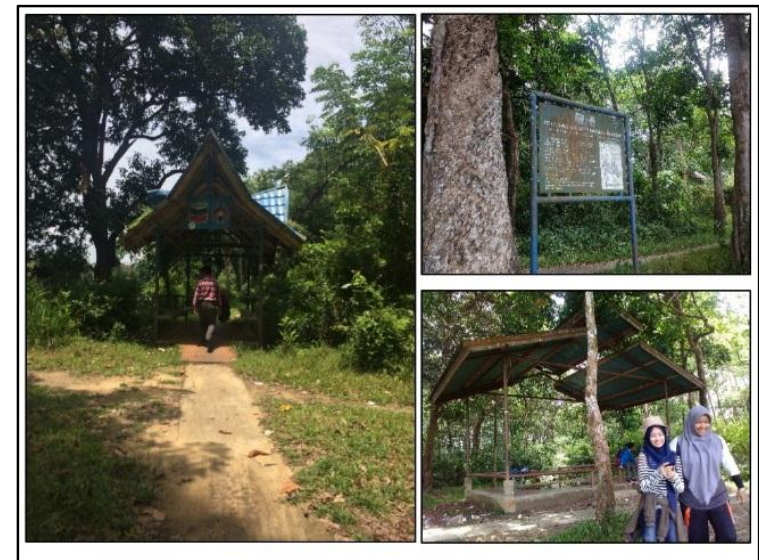

Fig. 9. Several facilities that have been built by PT. Chevron Pacific Indonesia

Aspects that must be addressed to increase the number of tourists to this area are:

1. The promotion of the region by organizing events locally, nationally and internationally

2. Improvement of public facilities such as signposts, public toilets, road improvements etc.

3. Establishing culinary locations and sale of souvenirs typical of the area.

4. Provision of homestay for travelers who want to stay in this area.

5. Presence of tour guide making it easier for tourists to explore the entire Geo-tourism site.

\section{Conclusion}

Several conclusions can be drawn from this study are:

1. Buluh Cina Village has the potential of geotourism can be developed that is the sand bar, oxbow lakes, tropical rain forests and ecotourism
2. Optimizing the utilization of Geotourism can be done to increase the number of tourists visiting this region

3. Keep doing repair of public facilities to support tourism activities in this area

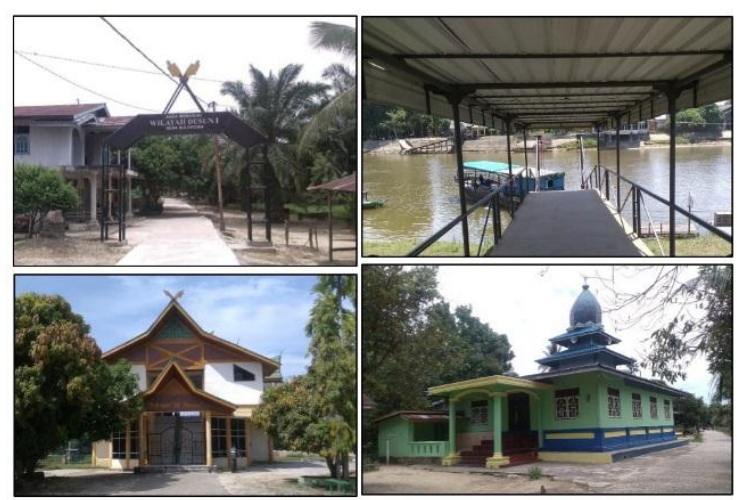

Fig. 10. Several existing facilities at Buluh Cina Village.

\section{Acknowledgements}

We would like to say thanks to Universitas Islam Riau for all the support, Tiggi Choanji and Adi Suryadi has helped in collecting data in the field and the students on The Department of Geological Engineering, Faculty of Engineering, Universitas Islam Riau for hel ping me on this research.

\section{References}

[1] Brahmantyo, B. (2008), "Menggali Akar Geowisata", Artikel Opini, Pikiran Rakyat, Bandung.

[2] Clarke, M.C.G et al (1982). Geological Map of The Pakanbaru Quadrangle, Sumatra. PPPG.

[3] Boggs, S. Jr. (2006). Principle of Sedimtology and Stratigrapy 4th ed, Pearson Prentice Hall, New Jersey, United States of America.

[4] Nichols, G. (2009). Sedimetology and Stratigraphy 2nd Ed, John Wiley \& Sons Ltd, West Sussex, United Kingdom.

[5] Page, K.J et al. (2003). Floodplain Formation and Sedimen Stratigraphy Resulting From Oblique Accretion on The Murrumbidgee River, Australia. Journal Of Sedimentary Research Vol. 73 No.1. Tulsa, Oklahoma, USA.

[5] Yuskar, Y and Choanji, T. (2016). Sediment Deposit of Floodplain Formation Resulting From Lateral Accretion Surfaces on Trpical Area: Study Case At Kampar River, Indonesia, The 7th IJJSS. 